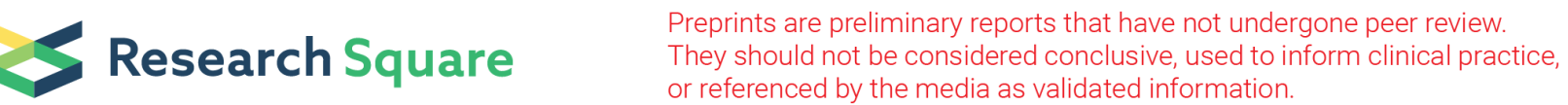

\section{Acute kidney injury in Plasmodium vivax malaria hospitalized patients in Manaus, Brazilian Amazon: are we underestimating the real burden?}

\section{Thalie Santos}

Fundacao de Medicina Tropical Doutor Heitor Vieira Dourado

Jose Diego Brito-Sousa

Fundacao de Medicina Tropical Doutor Heitor Vieira Dourado https://orcid.org/0000-0003-1659-3763

\section{Fernando Val}

Fundacao de Medicina Tropical Doutor Heitor Vieira Dourado

Jacqueline Sachett

Fundacao de Medicina Tropical Doutor Heitor Vieira Dourado

Miguel MD Moura

Fundacao Alfredo da Matta

\section{Nadia Cubas-Vega}

Universidade do Estado do Amazonas Escola Superior de Ciencias da Saude

\section{Paola López-Tejo}

Universidade do Estado do Amazonas Escola Superior de Ciencias da Saude

\section{Izabella Safe}

Fundacao de Medicina Tropical Doutor Heitor Vieira Dourado

\section{Rebeca Bessa}

Fundacao de Medicina Tropical Doutor Heitor Vieira Dourado

\section{Maria Graças Alecrim}

Fundacao de Medicina Tropical Doutor Heitor Vieira Dourado

\section{Karla Israel}

Universidade do Estado do Amazonas Escola Superior de Ciencias da Saude

Flor Martinez-Espinosa

Fundacao de Medicina Tropical Doutor Heitor Vieira Dourado

\section{Camila Bôtto-Menezes}

Fundacao de Medicina Tropical Doutor Heitor Vieira Dourado

\section{Gisely Melo}

Fundacao de Medicina Tropical Doutor Heitor Vieira Dourado

\section{Quique Bassat}

Instituto de Salud Global de Barcelona

\section{Marcus Lacerda}


Fundacao de Medicina Tropical Doutor Heitor Vieira Dourado

Wuelton Monteiro ( $\nabla$ wueltonmm@gmail.com )

Fundacao de Medicina Tropical Doutor Heitor Vieira Dourado

\section{Research}

Keywords: acute kidney injury, Plasmodium vivax, AKIN, malaria, severe malaria

Posted Date: November 22nd, 2019

DOI: https://doi.org/10.21203/rs.2.17608/v1

License: (c) (1) This work is licensed under a Creative Commons Attribution 4.0 International License. Read Full License 


\section{Abstract}

Background Acute kidney injury (AKI) is a common complication of Plasmodium falciparum malaria and can also occur secondary to P. malariae infections. Its association with P. vivax malaria is not well estimated neither understood.

Methods Retrospective assessment of medical records was conducted among P. vivax malaria hospitalized patients in a reference hospital of Manaus, Brazilian Amazon, from 2009 to 2017. AKI was classified according to Acute Kidney Injury Network (AKIN) criteria and through the World Health Organization (WHO) criteria for severe malaria. Patients diagnosed with primaquine-induced hemolysis due to confirmed glucose 6-phosphate dehydrogenase deficiency (G6PDd) and chronic renal failure were excluded. Prevalence of AKI and factors associated to this complication were assessed.

Results Out of 28,095 P. vivax malaria diagnoses during the study period in the reference center, 638 cases $(2.3 \%)$ required hospitalization; with $433(67.8 \%)$ of those patients having at least one creatinine measure. Twenty-two patients (5.1\%) were diagnosed with AKI as per WHO criteria; 241 patients presented more than two creatinine measures, of which 117 (49.2\%) patients had AKI per AKIN criteria. These were stratified in stage I $(n=88 ; 75.2 \%)$, stage II $(n=6 ; 5.1 \%)$, and stage III $(n=23 ; 19.6 \%)$. Major risk factor for AKI was older age. Renal replacement therapy (dialysis) was necessary in 6 cases $(1.4 \%)$.

Conclusions AKI secondary to vivax malaria was not unfrequent amongst hospitalized patients and may be a potentially severe complication. WHO diagnostic criteria for malaria AKI was shown to underestimate the real burden of AKI. Renal impairment should be closely monitored especially in older patients.

\section{Background}

Malaria remains a worldwide public health problem especially in Asia, Africa and Latin America. In 2017, 219 million cases and 435,000 deaths were estimated globally [1]. In Brazil, the great majority of malaria cases occur in the Amazon region, with Plasmodium vivax beingresponsible for nine out of every ten cases [1]. Although severe malaria has been historically associated to $P$. falciparum infection,an increasing number of reports has demonstrated the association between vivax malaria mono-infections and adverse outcomes [2-5].

Kidney involvement is relatively frequent in malaria caused by $P$. falciparum and $P$. malariae infections, being routinely associated to increased mortality and morbidity [6,7]. This condition may affect up to $40 \%$ of complicated cases of falciparum malaria, with mortality reaching $75 \%$ in some areas [8-10]. Hemodynamic dysfunction and immune response seem to play an important role in its pathogenesis [11]. In falciparum malaria, acute kidney injury (AKI) seems to be mediated by a complex interaction of mechanical, immune, acute phase response and hemodynamic factors [12]. The main kidney histopathological finding in falciparum malaria is acute tubular necrosis and, less frequently, interstitial nephritis and glomerulonephritis, suggesting a key role of hemodynamic factors in malaria-associated 
AKI [8]. Renal microcirculation blockade due to parasite erythrocytes sequestration play a central role in all aforementioned pathogenic factors of renal failure in falciparum malaria $[8,12]$. Unlike $P$. falciparum, $P$. malariae can cause chronic glomerulopathy that may relentlessly progress to end-stage renal disease, related to granular deposits through the endothelium with IgG, IgM, C3 and parasite antigens deposits [13-15].

Information about the clinical spectrum and pathogenesis of renal complications in vivax malaria is scarce. Although primaquine-induced hemolytic anemia in G6PD deficiency is considered a major underlying cause of renal injury in vivax malaria [16], some studies show the infection itself as cause of AKI [17-22]. Kidney dysfunction in vivax malaria was not associated with parasitemia levels, but with an imbalance in the IFN-Y/IL-10 ratio [23]. The number of AKI cases reported in previous publications is low and generally based on the definition established to diagnose cases of severe malaria of the World Health Organization (WHO) originally intended for $P$. falciparum disease, which is serum creatinine higher than $3.0 \mathrm{mg} / \mathrm{dL}$ [24]. This is a cross-sectional definition using a high cut off for serum creatinine, probably underestimating the AKI burden in vivax malaria patients. Thus, this study aimed to describe the morbidity of vivax malaria associated AKI in cases admitted to a referral institution in the Western Brazilian Amazon.

\section{Methods}

\section{Study site and case management}

Fundação de Medicina Tropical Dr Heitor Vieira Dourado (FMT-HVD) is a tertiary care reference center for diagnosis and treatment on infectious diseases in Manaus, Brazil (Western Brazilian Amazon). Upon presentation to the hospital outpatient clinics, every febrile patient is routinely screened for malaria infection, through thick blood smears (TBS). Antimalarial treatment is provided free of charge after a positive result. Brazilian Ministry of Health [25] recommends chloroquine (CQ, $25 \mathrm{mg}$ of base/kg over three days) plus a short 7-day course of primaquine ( $P Q, 0.5 \mathrm{mg}$ of base $/ \mathrm{kg} /$ day) for uncomplicated vivax malaria. All patient data are recorded in the hospital's electronic medical chart (iDoctor ${ }^{\circledR}$ ).

\section{Study design and data assessment}

A retrospective assessment of medical records was conducted aiming to identify all $P$. vivax malaria cases that required hospitalization, from 2009 to 2017. Patients suspected of primaquine-induced hemolysis were systematically submitted to a glucose 6-phosphate dehydrogenase deficiency (G6PDd) test, as per hospital protocol, and if deficient, were excluded. Likewise, patients self-reporting chronic renal failure were also excluded.

All laboratory and clinical data were retrieved from medical records using a structured questionnaire. Demographic data included age in years, sex, number of previous malarial infections and total time of hospitalization in days. Clinical data included the presence of comorbidities and concomitant conditions, 
signs of severe malaria according to WHO [26], need for dialysis, transfusion and intensive care, and death. Laboratory data included hemoglobin $(\mathrm{g} / \mathrm{dL})$, platelets $\left(\mathrm{x} 10^{3} / \mathrm{mm}^{3}\right)$, total and fractional bilirubin $(\mathrm{mg} / \mathrm{dL})$, lactate dehydrogenase $(\mathrm{U} / \mathrm{L})$, creatinine $(\mathrm{U} / \mathrm{L})$, urea $(\mathrm{U} / \mathrm{L})$, aspartate aminotransferase (AST) $(\mathrm{U} / \mathrm{L})$, and alanine aminotransferase (ALT) (U/L). This study followed Reporting of Studies Conducted using Observational Routinely-collected Data (RECORD) statement [27].

\section{Acute kidney injury (AKI) classification}

The onset of acute kidney injury was established according to the Acute Kidney Injury Network (AKIN) [28] and WHO criteria [29]. According to AKIN, the onset of AKI was based on the presence of one or more of the following, when available: i) abrupt increase in serum creatinine ( $\mathrm{SCr}$ ) levels $\geq 0.3 \mathrm{mg} / \mathrm{dL}$ within 48 hours; or ii) 1.5 -fold increase ( $\geq 50 \%$ ) from baseline SCr. The degree of injury was classified in three stages, depending on severity of renal impairment: i) stage I, when increased from $150 \%$ to $200 \%$ from baseline; ii) stage II, when increased from $200 \%$ to $300 \%$; and iii) stage III, when increased more than $300 \%$ from baseline or serum creatinine $\geq 4 \mathrm{mg} / \mathrm{dL}$. Presence and severity of AKI when there was no premorbid SCr measurement was also calculated by the difference between the highest measure during hospitalization (peak) and the lowest measure recorded (baseline) [30,31]. As for WHO criteria [29], renal impairment was defined as $\mathrm{SCr}>3 \mathrm{mg} / \mathrm{dL}$, in patients with at least one serum creatinine value available.

\section{Statistical analysis}

Descriptive statistical analysis was used for demographic and clinical data. Independent t tests or Wilcoxon Mann-Whitney, univariate logistic regression and chi-squared $\left(\chi^{2}\right)$ tests were used to compare groups stratified by two outcomes: acute kidney injury either by AKIN or WHO criteria. All statistical analyses were carried out using Stata v14 (StataCorp, Texas, USA).

\section{Ethical statement}

This study was approved by the Ethics Institutional Review Board at Universidade do Estado do Amazonas, Manaus, Brazil (2.758.880/2016). A waiver for informed consent was given by the IRB since data was obtained exclusively from the medical charts. Participant anonymity was kept in all steps of data assessment and analysis.

\section{Results}

A total of 28,095 vivax malaria cases were recorded between 2009 and 2017, of which 638 cases (2.3\%) required hospitalization. Of these, $433(67.8 \%)$ patients hat at least one creatinine assessment and were analyzed in this series (Figure 1). No significant differences in sex were observed, with $219(50.6 \%)$ of the patients being females, with mean age of 31.2 years $( \pm 20.9)$, with nearly three quarters not referring a 
previous malaria infection $(n=307 ; 73.4 \%)$. Twenty-two patients $(5.1 \%)$ were diagnosed with AKI as per WHO criteria. When more than two creatinine measures $(n=241)$ were available, 117 patients $(49.2 \%)$ had AKI per AKIN criteria, stratified according to AKIN stage as stage I $(n=88 ; 75.2 \%)$, stage II $(n=6$; $5.1 \%)$, and stage III $(n=23 ; 19.6 \%)$. Taking into account the number of patients developing any stage of $\mathrm{AKI}$, as per AKIN criteria, the prevalence of AKI was found to be $0.41 \%$ in the general population; as per WHO criteria, this prevalence fell to $0.07 \%$. Renal replacement therapy (dialysis) was necessary in 6 cases (1.4\%). Three deaths were recorded in patients presenting comorbidities or concomitant conditions $(0.7 \%)$. All admission data are summarized in table 1.

Regarding treatments administered, most patients received standard CQ plus PQ ( $n=359 ; 82.9 \%)$, and only a few CQ only $(n=47 ; 10.8 \%)$, standard treatment followed by other antimalarials $(n=4 ; 0.9 \%)$, or other antimalarials $(n=23 ; 5.3 \%)$. Of all patients, $113(26.1 \%)$ had at least one co-morbidity or concomitant clinical condition including arterial hypertension $(n=31 ; 27.4 \%)$, diabetes $(n=26 ; 23.0 \%)$, liver disease $(n=19 ; 16.8 \%)$, hematological diseases $(n=15 ; 13.3 \%)$, HIV infection $(n=12 ; 10.6 \%)$, pneumonia $(n=7 ; 6.2 \%)$, and pregnancy $(n=5 ; 4.4 \%)$.

When compared to the group with no AKI, the AKI group defined by WHO criteria ( 22 of $433,5.1 \%$ ) showed significant differences between mean age [43.2 years vs 30.5 years], first malarial episode [12 vs 295], presence of co-morbidities [10 vs 103], time of hospitalization [9.3 days vs 4.3 days; $p<0.001$ ], need for dialysis [6 vs 0], death [2 vs 1], need for blood transfusion [9 vs 52], total bilirubin [3.4 vs 1.4], urea [131 vs 26], and AST [79 vs 39]. Contrastingly, as per AKIN criteria ( 117 of $238,49.2 \%)$, only mean age [42.1 years vs 31.6 years], presence of co-morbidities [ $45 \mathrm{vs} \mathrm{32}$ ], time of hospitalization [5.6 days vs 4.5 days], need for dialysis [ 6 vs 0$]$, and urea [ $42 \mathrm{mg} / \mathrm{dL}$ vs $27 \mathrm{mg} / \mathrm{dL}$ ] showed significant differences compared to those without AKI per AKIN criteria. All data divided per diagnostic criteria are summarized in table 2 . When using only patients with at least two SCr values $(n=238,54.9 \%)$ for both criteria, the proportion of patients diagnosed by each was statistically different (22 WHO vs 117 AKIN). Of the 22 cases diagnosed by WHO criteria, 19 were AKIN stage III whilst the remaining 3 were AKIN stage II.

\section{Discussion}

Albeit being described frequently in most Plasmodium species, $P$. vivax malaria-associated AKI is less commonly reported worldwide. In this series, nearly half (49.2\%) of hospitalized patients developed AKI following $P$. vivax infection. This was dependent on which criteria, AKIN or WHO, was used for diagnosis. WHO classifies malaria AKI through a single SCr assessment [26]. However, according to the AKIN, two or more creatinine measurements should be used for diagnosis [32,33]. Despite accuracy increase associated to AKI diagnosis and classification, patients with malaria in several endemic areas do not always present serial measurements of markers, which impairs the use of more refined criteria, and is probably at the basis of the WHO recommendations. Nonetheless, a simple switch between both criteria may increase the prevalence of AKI in this population. Also, timely and accurate diagnosis may represent a decline in chronic morbidity associated to AKI post hospital discharge for these patients. 
AKI in malaria has a higher prevalence in older groups and is reported in up to $40 \%$ of severe cases of $P$. falciparum infection in adults [8,34]. Despite its overall lower prevalence, studies show similar severity among vivax cases $[17,35]$. Age and presence of comorbidities were independently associated with the development of AKI irrespective of criteria used for diagnosis. Additionally, first malarial infection also presented association to AKI when using WHO criteria. However, the probability of age being a confounder directly influencing the development of comorbidities and number of previous malaria episodes through lifetime needs to be contemplated.

Besides age, several factors are considered to be at risk for the development of malaria AKI, as hyperkalemia, hepatic dysfunction with hyperbilirubinemia, use of vasoactive drugs, leukocytosis and sepsis secondary to bacterial infections [36]. In addition, factors related to hemodynamics (hypovolemia), vascular (intravascular hemolysis, central and peripheral vasoconstriction and changes in microcirculation), cellular destruction (hemolysis and hemoglobinuria) and immune response (immune complexes deposition) may also contribute to the occurrence of renal complications $[8,17,37,38]$. The main clinical manifestations of AKI are oligo-anuria, severe metabolic acidosis, hypercatabolic state, and hydroelectrolytic disorders, such as hyponatremia and hyperkalemia [36]. In tropical areas, differential diagnoses of AKI among patients with acute febrile syndrome include, among others malaria, leptospirosis, hantavirosis, yellow fever, dengue and sepsis. Also, it is not infrequent in malaria to find sterile (mild or moderate) pyuria in the analysis of urinary sediment, which may erroneously lead to the diagnosis of acute febrile syndrome with urinary tract infection, thus triggering an unnecessary use of antimicrobials, some of which may reduce parasitemia, such as sulfas, clindamycin and quinolones, hindering the early parasitological diagnosis.

The pathogenesis of malaria associated AKI is not completely understood. The main histopathological findings involve acute tubular necrosis, acute nephropathy, interstitial nephritis, inflammatory interstitial infiltrate, edema and glomerulonephritis, with the main causes being renal microcirculation blockade, hemodynamic factors and hypovolemia [39,40]. Immune activation and the concomitant release of inflammatory mediators, along with endothelial activation, have also been associated with renal dysfunction secondary to malaria [41].

In this study, a limitation is that decisions over medical evaluation, laboratory assessments and patient discharge were based on attending clinician's discretion. As FMT-HVD is a referral center, the true prevalence of AKI in vivax malaria may be overestimated since most cases are already complicated when admitted to the institution. Nonetheless, it may stand as a good proxy for complicated vivax malaria cases where the onset of AKI is likely to occur.

In conclusion, prevalence of AKI was found to be high among hospitalized patients with vivax malaria, affecting nearly half of all vivax admissions. The prevalence varied according to the assessment tool, increasing almost 10 -fold with more than one SCr evaluation. Two or more SCr assessments should be performed in order to accurately and timely diagnose AKI in malaria patients when possible, avoiding further advancement of renal complications due to the delay of late recognition and proper initiation of 
specific treatment. Older patients with malaria should be screened for co-morbidities and followed-up closely, particularly for this dangerous complication. AKI related to vivax malaria is more prevalent than previously thought and needs to be properly monitored among hospitalized patients.

\section{List Of Abbreviations}

AKI - Acute kidney injury

AKIN - Acute kidney injury network

ALT - alanine aminotransferase

AST - aspartate aminotransferase

FMT-HVD - Fundação de Medicina Tropical Doutor Heitor Vieira Dourado (Manaus, Brazil)

G6PD - glucose 6-phosphate dehydrogenase

SCr - Serum creatinine

WHO - World Health Organization

\section{Declarations}

\section{Ethics approval and consent to participate}

This study was approved by the Ethics Institutional Review Board at Universidade do Estado do Amazonas, Manaus, Brazil (2.758.880/2016). A waiver for informed consent was given by the IRB since data was obtained exclusively from the medical charts. Participant anonymity was kept in all steps of data assessment and analysis.

\section{Acknowledgments}

We would like to thank the epidemiology department at the Fundação de Medicina Tropical Doutor Heitor Vieira Dourado (FMT-HVD) for providing the database used in this manuscript. ISGlobal is a member of the CERCA Program, Generalitat de Catalunya (http://cerca.cat/en/suma/). CISM is supported by the Government of Mozambique and the Spanish Agency for International Development (AECID).

\section{Funding}

This study was funded in part by the Research Support Foundation of Amazonas (FAPEAM) through the Call 005/2019 (PAPAC), and scholarships to scientific initiation and post-graduate support program to 
TCS and JDBS, respectively. WMM and MVGL are CNPq fellows. The funders had no role in study design, data collection, manuscript preparation or decision to publish.

\section{Authors' contributions}

Conceptualization: WMM FV

Database creation: TCS JDBS NCV PLT

Formal analysis: TCS JDBS FV JAGS WMM

Writing - first draft: TCS JDBS FV

Writing - revision, editing and critical analysis: TCS JDBS FV JAGS MM NCV PLT IS RB MGA KI FME CBM GM QB MVGL WMM

\section{Competing interests}

The authors declare no competing interests.

\section{Consent for publication}

N/A.

\section{Availability of data and material}

Please contact corresponding author for additional data requests.

\section{References}

1. World Health Organization. World Malaria Report 2018. Geneva: World Health Organization; 2018.

2. Val F, Machado K, Barbosa L, Salinas JL, Siqueira AM, Alecrim MGC, et al. Respiratory Complications of Plasmodium vivax Malaria: Systematic Review and Meta-Analysis. Am J Trop Med Hyg [Internet]. 2017;97:tpmd170131. Available from: http://www.ajtmh.org/content/journals/10.4269/ajtmh.170131

3. Lacerda MVG, Mourão MPG, Alexandre MAA, Siqueira AM, Magalhães BML, Martinez-Espinosa FE, et al. Understanding the clinical spectrum of complicated Plasmodium vivax malaria: a systematic review on the contributions of the Brazilian literature. Malar J [Internet]. Springer Nature; 2012;11:12. Available from: http://dx.doi.org/10.1186/1475-2875-11-12 
4. Lacerda MVG, Fragoso SCP, Alecrim MGC, Alexandre MAA, Magalhães BML, Siqueira AM, et al. Postmortem Characterization of Patients With Clinical Diagnosis of Plasmodium vivax Malaria: To What Extent Does This Parasite Kill? Clin Infect Dis [Internet]. 2012;55:e67-74. Available from: https://academic.oup.com/cid/article-lookup/doi/10.1093/cid/cis615

5. Lança EFC, Magalhães BML, Vitor-Silva S, Siqueira AM, Benzecry SG, Alexandre MAA, et al. Risk factors and characterization of plasmodium vivax-associated admissions to pediatric intensive care units in the brazilian amazon. PLoS One. 2012;

6. Kute VB, Trivedi HL, Vanikar A V., Shah PR, Gumber MR, Patel H V., et al. Plasmodium vivax malariaassociated acute kidney injury, India, 2010-2011. Emerg Infect Dis. 2012;

7. Rizvi I, Tripathi D, Zaman S, Zaidi N, Chughtai A, Beg M. Complications associated with Plasmodium vivax malaria: A retrospective study from a tertiary care hospital based in western Uttar Pradesh, India. Ann Afr Med. 2013;

8. Koopmans LC, Van Wolfswinkel ME, Hesselink DA, Hoorn EJ, Koelewijn R, Van Hellemond JJ, et al. Acute kidney injury in imported Plasmodium falciparum malaria. Malar J. 2015;

9. Hanson J, Hasan MM, Royakkers AA, Alam S, Charunwatthana P, Maude RJ, et al. Laboratory prediction of the requirement for renal replacement in acute falciparum malaria. Malar J. 2011;

10. van Wolfswinkel ME, Koopmans LC, Hesselink DA, Hoorn EJ, Koelewijn R, van Hellemond JJ, et al. Neutrophil gelatinase-associated lipocalin (NGAL) predicts the occurrence of malaria-induced acute kidney injury. Malar J [Internet]. 2016;15:464. Available from: https://doi.org/10.1186/s12936-0161516-y

11. Da Silva Junior GB, Pinto JR, Barros EJG, Farias GMN, Daher EDF. Kidney involvement in malaria: An update. Rev. Inst. Med. Trop. Sao Paulo. 2017.

12. Eiam-Ong S. Malarial nephropathy. Semin. Nephrol. 2003.

13. White RHR. Quartan malarial nephrotic syndrome. Nephron. 1973;11:147-62.

14. Walker A, Ellis J, Irama M, Senkungu J, Nansera D, Axton J, et al. Eosinophilic glomerulonephritis in children in Southwestern Uganda. Kidney Int [Internet]. Elsevier; 2007;71:569-73. Available from: https://doi.org/10.1038/sj.ki.5002085

15. Ward P, Kibukamusoke J. EVIDENCE FOR SOLUBLE IMMUNE COMPLEXES IN THE PATHOGENESIS OF THE GLOMERULONEPHRITIS OF QUARTAN MALARIA. Lancet [Internet]. Elsevier; 1969;293:283-5. Available from: https://doi.org/10.1016/S0140-6736(69)91038-1

16. Brito-Sousa JD, Santos TC, Avalos S, Fontecha G, Melo GC, Val F, et al. Clinical Spectrum of Primaquine-induced Hemolysis in G6PD Deficiency: A Nine-Year Hospitalization-Based Study from the Brazilian Amazon. Clin Infect Dis. 2019;

17. Naqvi R. Plasmodium vivax causing acute kidney injury: A foe less addressed. Pakistan J Med Sci. 2015;

18. Sundriyal D, Kumar N, Chandrasekharan A, Sharma B, Patnaik I, Kamble U. Fatal complications of Plasmodium vivax malaria: A series of three case reports. Ann Trop Med Public Heal. 2014; 
19. Meremo AJ, Kilonzo SB, Munisi D, Kapinga J, Juma M, Mwanakulya S, et al. Acute renal failure in a Caucasian traveler with severe malaria: a case report. Clin Case Reports. 2014;

20. Amitabh V, Kishore U, Singhal A, Patel N, Mishra P, Sudhir, et al. Acute renal failure due to Plasmodium vivax malaria - experience from a tertiary care centre. Journal, Indian Acad Clin Med. 2010;

21. Alexandre MA, Ferreira CO, Siqueira AM, Magalhães BL, Mourão MPG, Lacerda M V., et al. Severe Plasmodium vivax malaria, Brazilian Amazon. Emerg Infect Dis. 2010;16:1611-4.

22. Siqueira AM, Lacerda MVG, Magalhães BML, Mourão MPG, Melo GC, Alexandre MAA, et al. Characterization of Plasmodium vivax-associated admissions to reference hospitals in Brazil and India. BMC Med [Internet]. Springer Nature; 2015;13. Available from:

http://dx.doi.org/10.1186/s12916-015-0302-y

23. Cruz LAB, Barral-Netto M, Andrade BB. Distinct inflammatory profile underlies pathological increases in creatinine levels associated with Plasmodium vivax malaria clinical severity. PLoS Negl Trop Dis. 2018;12:e0006306.

24. World Health Organization. Severe falciparum malaria. Trans R Soc Trop Med Hyg. 2000;94:S1-90.

25. Brazilian Ministry of Health. Guia prático de tratamento da malária no Brasil. Brasília Ministério da Saúde. 2010;36.

26. WHO I Severe malaria. WHO - Trop Med Int Heal 19, Suppl 1 (November 2014). World Health Organization; 2014;125.

27. Nicholls SG, Quach P, Von Elm E, Guttmann A, Moher D, Petersen I, et al. The REporting of studies Conducted using Observational Routinely-collected health Data (RECORD) statement: Methods for arriving at consensus and developing reporting guidelines. PLoS One. 2015;

28. Mehta RL, Kellum JA, Shah S V, Molitoris BA, Ronco C, Warnock DG, et al. Acute Kidney Injury Network: report of an initiative to improve outcomes in acute kidney injury. Crit Care. 2007;11:R31.

29. World. Severe Malaria. Trop Med Int Heal [Internet]. John Wiley \& Sons, Ltd (10.1111); 2014;19:7131. Available from: https://doi.org/10.1111/tmi.12313_2

30. Chertow GM, Burdick E, Honour M, Bonventre J V., Bates DW. Acute Kidney Injury, Mortality, Length of Stay, and Costs in Hospitalized Patients. J Am Soc Nephrol. 2005;16:3365-70.

31. Hsu C-Y, McCulloch CE, Fan D, Ordoñez JD, Chertow GM, Go AS. Community-based incidence of acute renal failure. Kidney Int [Internet]. 2007;72:208-12. Available from:

http://www.pubmedcentral.nih.gov/articlerender.fcgi?artid = 2673495\&tool = pmcentrez\&rendertype = abstract

32. Kellum JA, Lameire N, Aspelin P, Barsoum RS, Burdmann EA, Goldstein SL, et al. Kidney disease: Improving global outcomes (KDIGO) acute kidney injury work group. KDIGO clinical practice guideline for acute kidney injury. Kidney Int Suppl. Nature Publishing Group; 2012;2:1.

33. Kellum JA, Lameire N, KDIGO AKI Guideline Work Group. Diagnosis, evaluation, and management of acute kidney injury: a KDIGO summary (Part 1). Crit Care. BioMed Central; 2013;17:204. 
34. Conroy AL, Hawkes M, Elphinstone RE, Morgan C, Hermann L, Barker KR, et al. Acute kidney injury is common in pediatric severe malaria and is associated with increased mortality. Open Forum Infect Dis. 2016;3:1-9.

35. Nayak KC, Kumar S, Gupta BK, Kumar S, Gupta A, Prakash P, et al. Clinical and histopathological profile of acute renal failure caused by falciparum and vivax monoinfection: an observational study from Bikaner, northwest zone of Rajasthan, India. J Vector Borne Dis. India; 2014;51:40-6.

36. Win KKYK, Thanachartwet $V$, Wattanagoon $Y$, Jerraksuwan $S$, Ruangweerayut R, Desakorn V. Factors associated with acute renal failure in adults with severe falciparum malaria. Southea2st Asian $\mathrm{J}$ Trop Med Public Heal. 2012;43:1071-9.

37. Kute VB, Trivedi HL, Vanikar A V, Shah PR, Gumber MR, Patel H V, et al. Plasmodium vivax Malariaassociated Acute Kidney Injury, India, 2010-2011. Emerg Infect Dis. United States; 2012;18:842-5.

38. Saravu K, Rishikesh K, Parikh CR. Risk factors and outcomes stratified by severity of acute kidney injury in malaria. PLoS One. 2014;9.

39. Elsheikha HM, Sheashaa HA. Epidemiology, pathophysiology, management and outcome of renal dysfunction associated with plasmodia infection. Parasitol Res. 2007;101:1183-90.

40. Nguansangiam S, Day NPJ, Hien TT, Mai NTH, Chaisri U, Riganti M, et al. A quantitative ultrastructural study of renal pathology in fatal Plasmodium falciparum malaria. Trop Med Int Heal. 2007;12:1037-50.

41. Silva Junior GB da, Pinto JR, Barros EJG, Farias GMN, Daher EDF, Da Silva Junior GB, et al. Kidney involvement in malaria: an update. Rev Inst Med Trop Sao Paulo. Instituto de Medicina Tropical de S\&atilde;o Paulo; 2017;59:1-6.

\section{Tables}

Table 1. Baseline characteristics of 433 participants hospitalized with vivax malaria and at least one creatinine measure available from 2009 to 2017. 


\begin{tabular}{|c|c|}
\hline Variable & Total $(n=433)$ \\
\hline Age in years (mean \pm SD) & $31.2( \pm 20.9)$ \\
\hline $\operatorname{Sex}(\mathrm{m} / \mathrm{f})$ & $214 / 219$ \\
\hline First malaria episode $(\mathrm{n} / \%)^{\mathrm{a}}$ & $307(73.4)$ \\
\hline \multicolumn{2}{|l|}{ Parasitemia at admission $(\mathrm{n} / \%)^{\mathrm{b}}$} \\
\hline$\leq 500$ parasites $/ \mathrm{mm}^{3}$ & $171(42.2)$ \\
\hline $501-10,000$ parasites $/ \mathrm{mm}^{3}$ & $173(42.7)$ \\
\hline$\geq 10,001$ parasites $/ \mathrm{mm}^{3}$ & $61(15.1)$ \\
\hline and concomitant conditions (n/\%) & $113(26.1)$ \\
\hline talization in $\mathrm{d}$ & $4.6( \pm 3.4)$ \\
\hline Dialysis $(\mathrm{n} / \%)$ & $6(1.4)$ \\
\hline Death $(n / \%)$ & $3(0.7)$ \\
\hline Blood transfusion (n/\%) & $(14.2)$ \\
\hline Hemoglobin $(\mathrm{g} / \mathrm{dL})(\text { mean } \pm \mathrm{SD})^{\mathrm{c}}$ & $10.3( \pm 2.5)$ \\
\hline Platelet count $\left(\times 10^{3} / \mathrm{mm}^{3}\right)$ median $(\mathrm{IQR})^{\mathrm{C}}$ & $42(75-665)$ \\
\hline Creatinine (mg/dL) median (IQR) & $.1-17.4)$ \\
\hline Urea $(\mathrm{mg} / \mathrm{dL})$ median $(\mathrm{IQR})^{\mathrm{d}}$ & $-455)$ \\
\hline Bilirubin $(\mathrm{mg} / \mathrm{dL})$ median $(\mathrm{IQR})^{\mathrm{e}}$ & $1.4(0.2-32.0)$ \\
\hline Conjugated bilirubin $(\mathrm{mg} / \mathrm{dL})$ median $(\mathrm{IQR})^{\mathrm{e}}$ & $0.5(0.03-24.0)$ \\
\hline Unconjugated bilirubin (mg/dL) median $(\mathrm{IQR})^{\mathrm{e}}$ & $0.7(0.05-21.3)$ \\
\hline Lactate dehydrogenase $(\mathrm{U} / \mathrm{L})$ median $(\mathrm{IQR})^{\mathrm{f}}$ & $634(80-6418)$ \\
\hline AST $(\mathrm{U} / \mathrm{L})$ median $(\mathrm{IQR})^{\mathrm{g}}$ & $40(8-836)$ \\
\hline $\operatorname{lan}(\mathrm{IQR})^{\mathrm{g}}$ & $38(1-623)$ \\
\hline WHO Acute Kidney Injury (n/\%)* & $22(5.1)$ \\
\hline AKIN Acute Kidney Injury (n/\%)** & $117(49.2)$ \\
\hline Stage I $(\mathrm{n} / \%)$ & $88(75.2)$ \\
\hline Stage II $(n$ & \\
\hline Stage III $(\mathrm{n} / \%)$ & $23(19.6)$ \\
\hline
\end{tabular}

Completeness of data: ${ }^{a} 96.5 \%,{ }^{b} 93.5 \%,{ }^{c} 98.6 \%,{ }^{d} 91.4 \%,{ }^{e} 80.8 \%,{ }^{f} 38.7 \%,{ }^{g} 87.9 \%$, and $100 \%$ if not indicated otherwise. Abbreviations: WHO, World Health Organization; AKIN, Acute Kidney Injury Network. ${ }^{*}$ calculated on 433 patients with at least one creatinine measure; ** calculated on 238 patients with $\geq 2$ creatinine measures.

Table 2. Baseline characteristics of participants hospitalized with vivax malaria using AKI classification according to World Health Organization (WHO) and Acute Kidney Injury Network (AKIN) criteria from 2009 to 2017. 


\begin{tabular}{|c|c|c|c|c|c|c|c|c|}
\hline \multirow[t]{2}{*}{ Variable } & \multicolumn{4}{|c|}{$\begin{array}{l}\text { WHO criteria } \\
(\mathrm{n}=433)\end{array}$} & \multicolumn{4}{|c|}{$\begin{array}{l}\text { AKIN criteria } \\
(\mathrm{n}=238)\end{array}$} \\
\hline & $\begin{array}{l}\text { Yes (22; } \\
5.1 \%)\end{array}$ & No & $\begin{array}{l}p \\
\text { value }\end{array}$ & $\begin{array}{l}\text { OR } \\
(95 \% C I)\end{array}$ & $\begin{array}{l}\text { Yes } \\
(117 ; \\
49.2 \%)\end{array}$ & No & $\begin{array}{l}p \\
\text { value }\end{array}$ & $\begin{array}{l}\text { OR } \\
(95 \% C I)\end{array}$ \\
\hline Age in years (mean $\pm S D)$ & $\begin{array}{l}43.7 \\
( \pm 20.6)\end{array}$ & $\begin{array}{l}30.5 \\
( \pm 20.8)\end{array}$ & 0.003 & $\begin{array}{l}1.03 \\
(1.01- \\
1.05)\end{array}$ & $\begin{array}{l}42.1 \\
( \pm 18.9)\end{array}$ & $\begin{array}{l}31.6 \\
( \pm 20.6)\end{array}$ & 0.001 & $\begin{array}{l}1.02 \\
(1.01- \\
1.04)\end{array}$ \\
\hline $\operatorname{Sex}(m / f)$ & $15 / 7$ & $199 / 212$ & 0.07 & $\begin{array}{l}2.3 \\
(0.91- \\
5.71)\end{array}$ & $64 / 53$ & $58 / 63$ & 0.29 & $\begin{array}{l}1.31 \\
(0.78- \\
2.18)\end{array}$ \\
\hline $\begin{array}{l}\text { First malaria episode } \\
(\mathrm{n} / \%)\end{array}$ & $\begin{array}{l}12 \\
(54.5)\end{array}$ & $\begin{array}{l}295 \\
(74.5)\end{array}$ & 0.04 & $\begin{array}{l}0.41 \\
(0.17- \\
0.97)\end{array}$ & $\begin{array}{l}72 \\
(64.8)\end{array}$ & $\begin{array}{l}86 \\
(74.1)\end{array}$ & 0.13 & $\begin{array}{l}0.6 \\
(0.36- \\
1.13)\end{array}$ \\
\hline \multicolumn{9}{|l|}{$\begin{array}{l}\text { Parasitemia at admission } \\
(\mathrm{n} / \%)\end{array}$} \\
\hline$\leq 500$ parasites $/ \mathrm{mm}^{3}$ & $\begin{array}{l}10 \\
(47.6)\end{array}$ & $\begin{array}{l}161 \\
(41.9)\end{array}$ & 0.61 & $\begin{array}{l}1.25 \\
(0.52- \\
3.03)\end{array}$ & $\begin{array}{l}42 \\
(36.8)\end{array}$ & $\begin{array}{l}49 \\
(45.4)\end{array}$ & 0.19 & $\begin{array}{l}0.70 \\
(0.41- \\
1.20)\end{array}$ \\
\hline $\begin{array}{l}501-10,000 \\
\text { parasites } / \mathrm{mm}^{3}\end{array}$ & $6(28.5)$ & $\begin{array}{l}167 \\
(43.5)\end{array}$ & 0.17 & $\begin{array}{l}0.51 \\
(0.19- \\
1.36)\end{array}$ & $\begin{array}{l}55 \\
(48.2)\end{array}$ & $\begin{array}{l}42 \\
(38.8)\end{array}$ & 0.16 & $\begin{array}{l}1.46 \\
(0.85- \\
2.49)\end{array}$ \\
\hline$\geq 10,001$ parasites $/ \mathrm{mm}^{3}$ & $5(23.8)$ & $\begin{array}{l}56 \\
(14.6)\end{array}$ & 0.25 & $\begin{array}{l}1.83 \\
(0.64- \\
5.19)\end{array}$ & $\begin{array}{l}17 \\
(14.9)\end{array}$ & $\begin{array}{l}17 \\
(15.7)\end{array}$ & 0.86 & $\begin{array}{l}0.93 \\
(0.45- \\
1.94)\end{array}$ \\
\hline $\begin{array}{l}\text { Comorbidities and } \\
\text { concomitant conditions } \\
\text { (n/\%) }\end{array}$ & $\begin{array}{l}10 \\
(45.5)\end{array}$ & $\begin{array}{l}103 \\
(25.1)\end{array}$ & 0.03 & $\begin{array}{l}2.49 \\
(1.04- \\
5.93)\end{array}$ & $\begin{array}{l}45 \\
(38.5)\end{array}$ & $\begin{array}{l}32 \\
(26.4)\end{array}$ & 0.04 & $\begin{array}{l}1.73 \\
(1.01- \\
3.01)\end{array}$ \\
\hline $\begin{array}{l}\text { Time of hospitalization in } \\
\text { days (mean } \pm \text { SD) }\end{array}$ & $\begin{array}{l}9.3 \\
( \pm 5.4)\end{array}$ & $\begin{array}{l}4.3 \\
( \pm 3.1)\end{array}$ & $<0.001$ & $\begin{array}{l}1.25 \\
(1.15- \\
1.37)\end{array}$ & $\begin{array}{l}5.6 \\
( \pm 4.1)\end{array}$ & $\begin{array}{l}4.5 \\
( \pm 2.8)\end{array}$ & 0.02 & $\begin{array}{l}1.09 \\
(1.01- \\
1.18)\end{array}$ \\
\hline Dialysis (n/\%) & $6(27.3)$ & - & $<0.001$ & - & $6(5.1)$ & - & 0.01 & - \\
\hline Death (n/\%) & $2(9.1)$ & $1(0.2)$ & $<0.001$ & - & $3(2.5)$ & - & 0.07 & - \\
\hline Blood transfusion (n/\%) & $9(42.8)$ & $\begin{array}{l}52 \\
(12.7)\end{array}$ & $<0.001$ & $\begin{array}{l}5.16 \\
(2.07- \\
12.85)\end{array}$ & $\begin{array}{l}24 \\
(20.7)\end{array}$ & $\begin{array}{l}48 \\
(11.7)\end{array}$ & 0.06 & $\begin{array}{l}1.97 \\
(0.96- \\
4.04)\end{array}$ \\
\hline $\begin{array}{l}\text { Hemoglobin }(\mathrm{g} / \mathrm{dL}) \\
(\text { mean } \pm \text { SD) }\end{array}$ & $\begin{array}{l}9.5 \\
( \pm 3.8)\end{array}$ & $\begin{array}{l}10.4 \\
( \pm 2.5)\end{array}$ & 0.09 & $\begin{array}{l}0.87 \\
(0.74- \\
1.03)\end{array}$ & $\begin{array}{l}10.5 \\
( \pm 2.8)\end{array}$ & $\begin{array}{l}10.4 \\
( \pm 2.5)\end{array}$ & 0.69 & $\begin{array}{l}1.01 \\
(0.92- \\
1.12)\end{array}$ \\
\hline $\begin{array}{l}\text { Platelet count }\left(\mathrm{x} 10^{3} / \mathrm{mm}^{3}\right) \\
\text { median (IQR) }\end{array}$ & $\begin{array}{l}63(8- \\
536)\end{array}$ & $\begin{array}{l}42(75- \\
665)\end{array}$ & 0.16 & 1 & $\begin{array}{l}36(5- \\
536)\end{array}$ & $\begin{array}{l}41.5(1- \\
665)\end{array}$ & 0.59 & 1 \\
\hline $\begin{array}{l}\text { Urea }(\mathrm{mg} / \mathrm{dL}) \text { median } \\
(\mathrm{IQR})\end{array}$ & $\begin{array}{l}131(23- \\
455)\end{array}$ & $\begin{array}{l}26(3- \\
157)\end{array}$ & $<0.001$ & $\begin{array}{l}1.04 \\
(1.02- \\
1.06)\end{array}$ & $\begin{array}{l}42(3- \\
455)\end{array}$ & $\begin{array}{l}27(5- \\
134)\end{array}$ & $<0.001$ & $\begin{array}{l}1.03 \\
(1.02- \\
1.05)\end{array}$ \\
\hline $\begin{array}{l}\text { Bilirubin (mg/dL) median } \\
\text { (IQR) }\end{array}$ & $\begin{array}{l}3.4(0.4- \\
15.8)\end{array}$ & $\begin{array}{l}1.4(0.2- \\
32.0)\end{array}$ & 0.04 & $\begin{array}{l}1.10 \\
(1.02- \\
1.19)\end{array}$ & $\begin{array}{l}2.31 \\
(0.18- \\
15.8)\end{array}$ & $\begin{array}{l}1.47 \\
(0.27- \\
32.0)\end{array}$ & 0.07 & $\begin{array}{l}1.01 \\
(0.94- \\
1.08)\end{array}$ \\
\hline $\begin{array}{l}\text { Conjugated bilirubin } \\
(\mathrm{mg} / \mathrm{dL}) \text { median (IQR) }\end{array}$ & $\begin{array}{l}1.0(0.1- \\
14.2)\end{array}$ & $\begin{array}{l}0.5(0.1- \\
24.0)\end{array}$ & 0.05 & $\begin{array}{l}1.15 \\
(1.02- \\
1.29)\end{array}$ & $\begin{array}{l}0.88 \\
(0.05- \\
14.2)\end{array}$ & $\begin{array}{l}0.53 \\
(0.03- \\
13.1)\end{array}$ & 0.10 & $\begin{array}{l}1.05 \\
(0.94- \\
1.18)\end{array}$ \\
\hline $\begin{array}{l}\text { Unconjugated bilirubin } \\
\text { (mg/dL) median (IQR) }\end{array}$ & $\begin{array}{l}0.9(0.1- \\
8.7)\end{array}$ & $\begin{array}{l}0.7(0.5- \\
21.3)\end{array}$ & 0.10 & $\begin{array}{l}1.11 \\
(0.94- \\
1.30)\end{array}$ & $\begin{array}{l}0.93 \\
(0.05- \\
8.7)\end{array}$ & $\begin{array}{l}0.81 \\
(0.12- \\
21.3)\end{array}$ & 0.15 & $\begin{array}{l}0.98 \\
(0.86- \\
1.11)\end{array}$ \\
\hline $\begin{array}{l}\text { Lactate dehydrogenase } \\
(\mathrm{U} / \mathrm{L}) \text { median (IQR) }\end{array}$ & $\begin{array}{l}782 \\
(219- \\
6418)\end{array}$ & $\begin{array}{l}632(80- \\
2115)\end{array}$ & 0.08 & 1 & $\begin{array}{l}610 \\
(219- \\
6418)\end{array}$ & $\begin{array}{l}671 \\
(311- \\
1843)\end{array}$ & 0.34 & 1 \\
\hline AST (U/L) median (IQR) & $\begin{array}{l}79(10- \\
560)\end{array}$ & $\begin{array}{l}39(8- \\
836)\end{array}$ & 0.006 & 1 & $\begin{array}{l}47(8- \\
743)\end{array}$ & $\begin{array}{l}38(11- \\
836)\end{array}$ & 0.16 & 1 \\
\hline ALT(U/L) median (IQR) & $\begin{array}{l}71(7- \\
228)\end{array}$ & $\begin{array}{l}37(1- \\
623)\end{array}$ & 0.08 & 1 & $\begin{array}{l}51(4- \\
623)\end{array}$ & $\begin{array}{l}35(1- \\
551)\end{array}$ & 0.07 & 1 \\
\hline
\end{tabular}


Per WHO criteria, 433 patients had at least one creatinine measure. Per AKIN criteria, 238 had at least 2 creatinine measures. T-test or Wilcoxon-Mann-Whitney according to normality were used. Pearson Chi squared test was used to compare proportions. Univariate logistic regression was used to verify the association between independent and dependent variables.

\section{Figures}

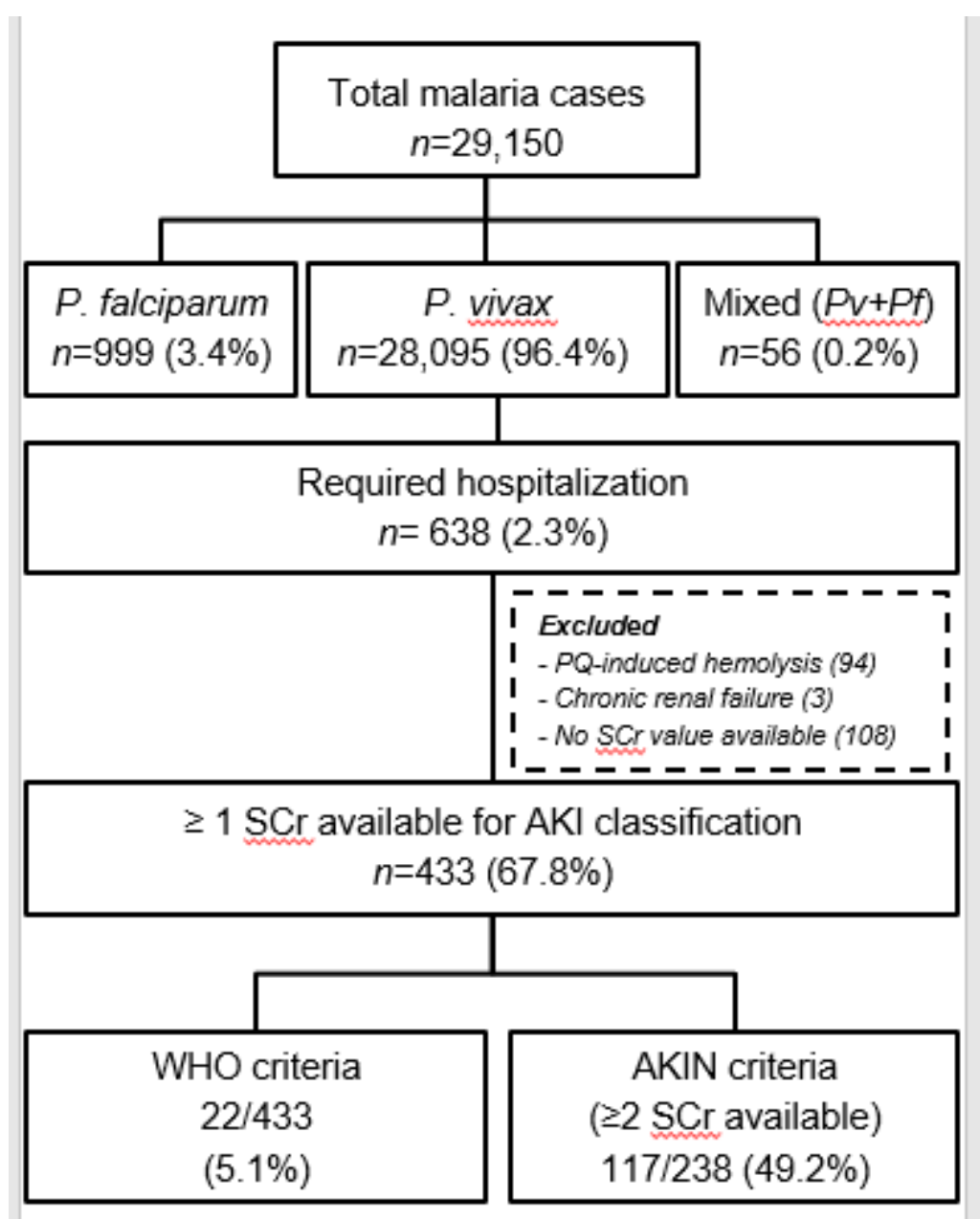

Figure 1

Flowchart of malaria cases diagnosed in a tertiary reference unit in Manaus, Western Brazilian Amazon between 2009 and 2017. Renal impairment by WHO defined as SCr $>3 \mathrm{mg} / \mathrm{dL}$ in patients with at least one serum creatinine value available and AKIN was based on: i) abrupt increase in serum creatinine ( $\mathrm{SCr}$ ) levels $\geq 0.3 \mathrm{mg} / \mathrm{dL}$ within 48 hours; or ii) 1.5 -fold increase ( $\geq 50 \%)$ from baseline SCr. The degree of injury was classified in three stages, depending on severity of renal impairment: i) stage I, when increased from $150 \%$ to $200 \%$ from baseline; ii) stage II, when increased from $200 \%$ to $300 \%$; and iii) stage III, when increased more than $300 \%$ from baseline or serum creatinine $\geq 4 \mathrm{mg} / \mathrm{dL}$. $\mathrm{PQ}$, primaquine; $\mathrm{SCr}$, serum creatinine; AKI, acute kidney injury; WHO, world health organization; AKIN, acute kidney injury network. 